\title{
A RANGE OF NEW FUNCTIONAL APPLICATIONS TO THE BUILDING OF HERITAGE BANK INDONESIA
}

\author{
${ }^{1}$ Devina Veronika. ${ }^{2}$ Yenny Gunawan, S.T., M.A. \\ ${ }^{\prime}$ Student in the Bachelor's (S-1) Study Program in Architecture at \\ Parahyangan Catholic University \\ ${ }^{2}$ Senior lecturer in the Bachelor's (S-1) Study Program in Architecture at \\ Parahyangan Catholic University
}

\begin{abstract}
The city district known as Senen forms one of the historical parts of Jakarta where there are many buildings to be found in the Dutch East Indies Empire style as architectural relics of the Dutch Colonial Era, and the majority of these buildings are still there, up to the present. Many of these relics of the past have not been properly maintained and have suffered damage. One of these happens to be the Heritage Bank Indonesia building situated at Jalan Prapatan No.42 in Jakarta. After its conservation and re-use, a functional change has taken place that is quite drastic when considered from its establishment until the present. This research study can be categorized as qualitative. The research method consists of the descriptive method along with the analytical and interpretative methods. The data have been analyzed by drawing a comparison between the building in its initial state and its current condition, which was subsequently processed based on the conservation principles issued by the regional authorities called Perda. The data collection technique was employed with the observational method, interviews, taking measurements, and by way of studying the relevant background literature. The conclusion of this research study is that the building of the Heritage Bank Indonesia is nothing but a piece of sculpture after its conservation because it has become isolated or alienated from its surroundings, and as such it is no longer in keeping with its environmental context, which is situated in the Learning center complex of Bank Indonesia.
\end{abstract}

Keywords: variety of new functional applications, Dutch East Indies Empire style of architecture, Heritage Bank Indonesia building

\section{RAGAM PENERAPAN FUNGSI BARU PADA BENTUK BANGUNAN HERITAGE BANK INDONESIA}

\author{
${ }^{1}$ Devina Veronika 2 Yenny Gunawan, ST., MA. \\ ${ }^{1}$ Mahasiswi S1 Program Studi Arsitektur Universitas Katolik Parahyangan. \\ 2 Dosen Pembimbing S1 Program Studi Arsitektur Universitas Katolik Parahyangan.
}

\begin{abstract}
Abstrak- Kawasan Senen merupakan salah satu kawasan bersejarah di Jakarta yang banyak terdapat bangunanbangunan bergaya indis peninggalan Belanda dan sebagian besar masih tersisa sampai kini. Banyak

${ }^{1}$ Corresponding author: devina.veronika@icloud.com
\end{abstract}


bangunan peninggalan tersebut yang tidak terawat dan mengalami kerusakan. Salah satunya adalah bangunan heritage Bank Indonesia yang terletak di Jalan Prapatan No. 42, Jakarta. Setelah bangunan Heritage Bank Indonesia ini dikonservasi dan digunakan kembali, terjadi perubahan fungsi yang cukup drastis dari awal berdiri hingga sekarang. Jenis penelitian ini berupa penelitian kualitatif. Metode penelitian adalah metode deskriptif, analitis, dan interpretatif. Data dianalisa dengan melakukan perbandingan antara bangunan di kondisi awal dengan bangunan di zaman sekarang, kemudian diolah berdasarkan prinsip konservasi dari Perda, jurnal, serta pedoman-pedoman dari ahli konservasi, dan prinsip penataan arsitektur (ordering principles). Teknik pengumpulan data dilakukan dengan metode observasi, wawancara, mengukur, dan melalui studi literatur. Kesimpulan dari penelitian ini adalah bangunan heritage Bank Indonesia setelah dikonservasi hanya seperti sculpture karena bangunan menjadi terasingkan dan tidak sesuai dengan konteks lingkungannya yang berada di dalam kompleks learning center Bank Indonesia.

Kata Kunci: ragam penerapan fungsi baru, arsitektur indis, konservasi, bangunan heritage Bank Indonesia

\section{PENDAHULUAN}

Kawasan Senen merupakan salah satu kawasan bersejarah yang banyak terdapat bangunanbangunan bergaya indis dan sebagian masih tersisa sampai kini, namun dalam kondisi yang tidak terawat. Pada zaman dahulu, di daerah Senen termasuk Jalan Prapatan banyak didirikan perumahan opsi-opsir Belandadan gedung-gedung milik tuan tanah, sedangkan di Jalan Gunung Sahari di sepanjang kali Ciliwung banyak pejabat-pejabat Belanda yang mendirikan pusat peristirahatan, sehingga pada abad ke 18 wilayah ini termasuk wilayah elit.

Salah satu bangunan bersejarah tersebut adalah bangunan bergaya arsitektur indissebagai salah satu produk akulturasi budaya Kolonial Belanda dengan kearifan lokal budaya Jawa yang terletak di Jalan Prapatan No. 42

Bangunan heritage milik Bank Indonesia ini terletak di dalam kompleks learning center Bank Indonesia dan telah berdiri sejak tahun 1800-an. Seiring perkembangannya, bangunan ini telah mengalami berbagai perubahan sejak awal dibangun hingga sekarang, baik dari segi fungsi maupun bentuk.

Penelitian ini bertujuan untuk mengetahui bagaimana tindakan konservasi yang dilakukan pada bangunan heritage Bank Indonesia, serta untuk mengetahui bagaimana perubahanbentuk (ruang, material, struktur) pada bangunan heritage Bank Indonesia yang terletak di Jl. Prapatan No. 42, dan ragam penerapan fungsi baru pada bangunan tersebut.

\section{TEORI KONSERVASI SERTA FUNGSI, BENTUK, DAN RUANG PADA BANGUNAN ARSITEKUR INDIS}

Teori yang dipakai dalam mengkaji penelitian ini adalah mengenai arsitektur indis, pedoman dan prinsip dalam konservasi bangunan tua, serta teori fungsi, bentuk, dan ruang, mencakup prinsip penataan dalam arsitektur (ordering principles).

\section{Arsitektur Indis}

Arsitektur indis merupakan percampuran antara budaya Belanda (Eropa) dengan budaya Jawa (lokal) yang terjadi akibat proses akulturasi yang panjang (Soekiman, 2000). Arsitektur indis merupakan adaptasi dan gabungan antara arsitektur Belanda dengan arsitektur lokal. Bangunan 
bergaya arsitektur indis memiliki penyesuaian dan respon terhadap iklim juga kultur setempat, serta menggunakan bahan-bahan lokal dengan mempertimbangan bangunan tradisional dan vernacular (Atmadi P, 1988).

\section{Konservasi Bangunan Cagar Budaya}

Dalam melakukan konservasi bangunan cagar budaya dibutuhkan pemahaman mengenai prinsip-prinsip dasar dalam proses konservasi tersebut, sehingga bangunan cagar budaya tersebut dapat dikonservasi secara tepat. Selain itu juga dibutuhkan panduan dalam tindakan konservasi tersebut.

\section{Prinsip-Prinsip Dasar Konservasi Bangunan Cagar Budaya}

Prinsip-prinsip dasar dalam melakukan konservasimenurut Mundarjito (UI 2002, dalam Jurnal FT UMJ 2005:3) dan menurut Andi Muliadi, S.S dalam jurnal tulisannya yang berjudul Upaya Penanganan Kayu Secara Tradisional antara laindijabarkan sebagai berikut:(1) Berdasar pada bukti dan mengutamakan keaslian (2) Memahami setiap tahapan atau lapisan (3) Memperhatikan tatanan dan (4) konteks serta penggunaan yang sesuai (5) Penggunaan yang sesuai (6) Perbaikan material (7) Tradisi dan teknologi (8) Kemudahan dibaca (9) Patina waktu (10) Keaslian Tata Letak.

\section{Panduan Tindakan Konservasi Bangunan Cagar Budaya}

Dalam melakukan tindakan konservasi perlu dicermati dan teliti. Panduan dalam tindakan konservasi bangunan cagar budaya dapat dilakukan menurut material bangunan tersebut. Material yang berbeda memerlukan penanganan yang berbeda pula. Panduan Dalam Melakukan Konservasi (berdasarkan material) dapat dibagi menjadi: (1) Material bata, batu, beton, dan plesteran pada eksterior (2) Material kayu (3) Material besi, baja, timah, alumunium, tembaga, seng (4) Atap (5) Jendela (6) Bangunan tambahan baru pada bangunan cagar budaya. Jadi, sebelum melakukan proses konservasi diperlukan adanya pemahaman mengenai prinsip-prinsip dasar. Dilanjutkan dengan penanganan dan tindakan yang tepat, yaitu dengan cara melakukan pemeriksaan material bangunan, kemudian, penanganan tindakan konservasi dapat dilakukan sesuai material bangunan tersebut.

\section{PEMBAHASAN}

\subsection{ANALISA PERUBAHAN BANGUNAN HERITAGE BANK INDONESIA}

Setelah hampir 200 tahun bangunan heritage Bank Indonesia ini berdiri, bangunan ini telah beberapa kali berganti fungsi, selain itu juga terdapat transformasi yang cukup dominan, yaitu perubahan pada penataan tapak dan penambahan beberapa massa bangunan.

Konservasi yang dilakukan oleh pihak BI dan konsultan dilakukan pada beberapa bagian bangunan yaitu pada: massa bangunan (badan dan atap bangunan), struktur bangunan, ornamen, penutup lantai, plafond, dll. 


\section{Perubahan Penataan Massa di Dalam Tapak}
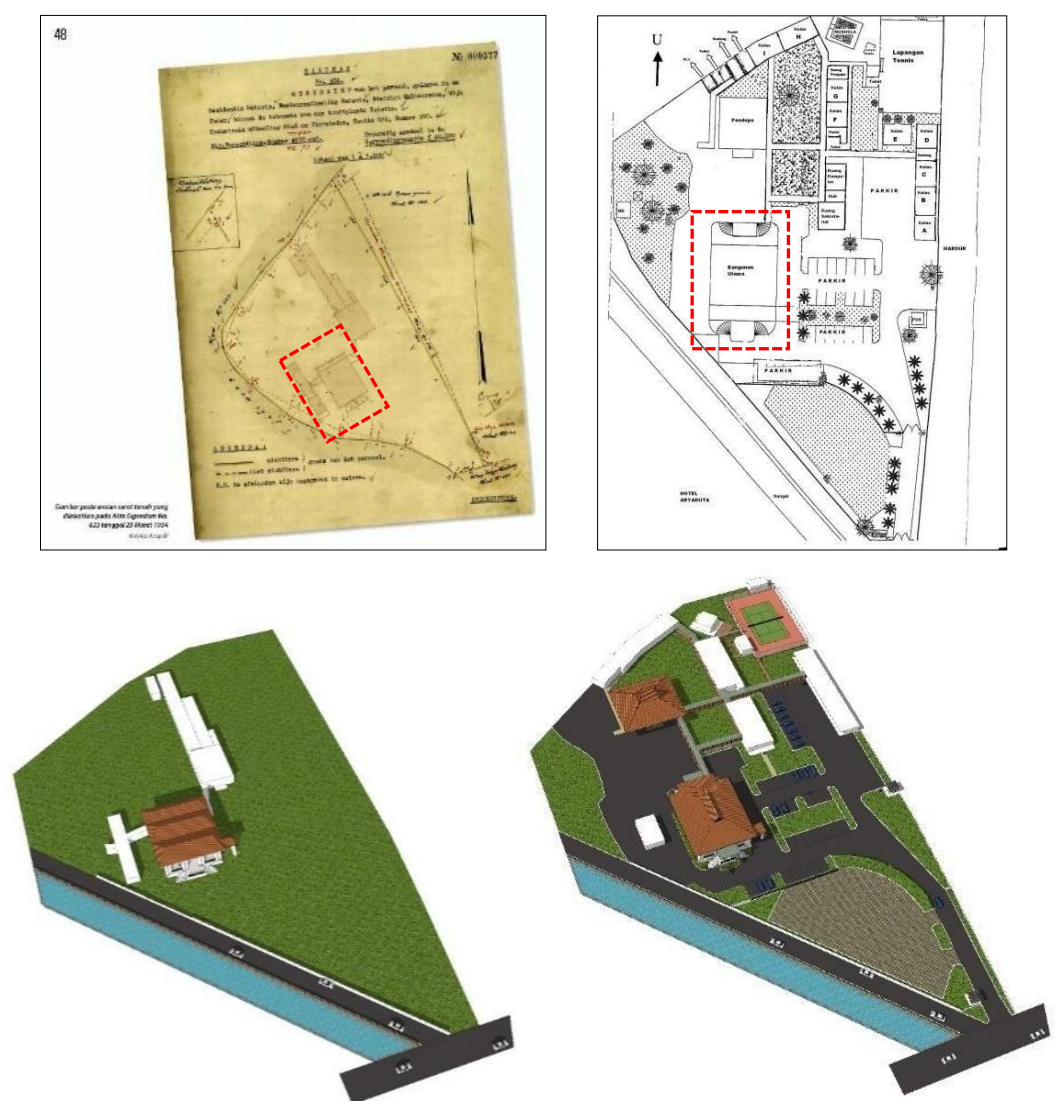

Figur 1. Penataan Massa Bangunan Pada Tapak (Kondisi Awal dan Kondisi Sekarang) (Sumber: Dokumentasi Pribadi)

(Figur 1) berisi perkiraan keadaan awal bangunan heritage Bank Indonesia. Terdapat bangunan tambahan di samping yang terhubung langsung dengan bangunan utama. Pada kondisi sekarang, masih terdapat bangunan tambahan, namun bangunan tambahan ini sudah tidak terhubung secara langsung oleh selasar (akses melalui luar bangunan utama)
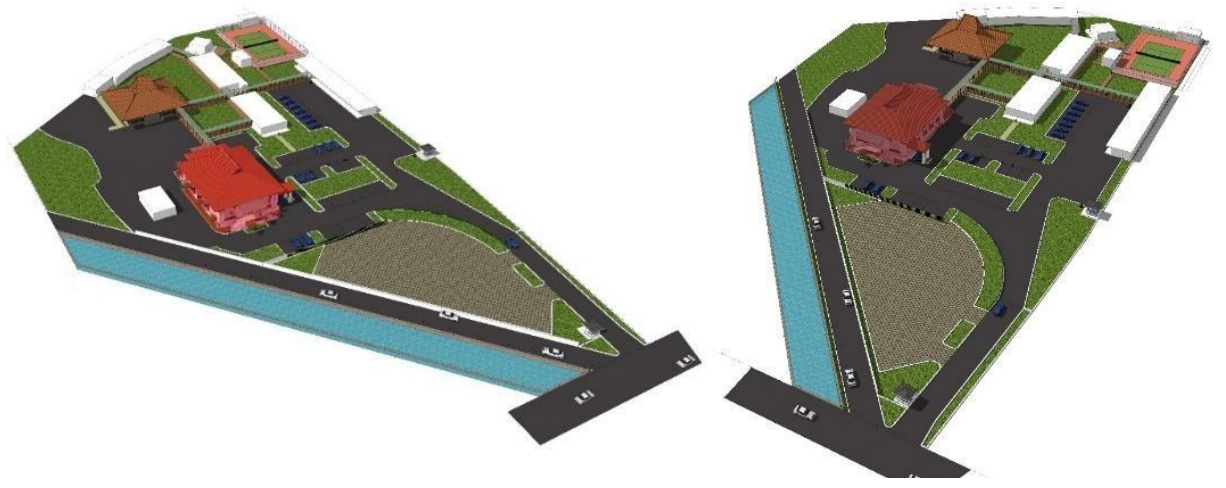

Figur 2. Hirarki Utama Massa Bangunan (Sumber : Dokumentasi Pribadi) 
Pada kawasan learning center Bank Indonesia Hirarki utama adalah bangunan heritage Bank Indonesia, berdasarkan bentuk yang lebih menonjol, ukuran dominan, ornamen yang detail dan mewah, serta fungsi bangunan yang berbeda dengan konteks lingkungannya.

\section{Perubahan Bentuk Bangunan Massa Bangunan}

Massa bangunan terdiri dari atap dan badan bangunan. Massa bangunan mengalami perubahan yang cukup drastis dari bentuk awalnya dibangun hingga sekarang.

\section{(1) Badan bangunan}

Rumah-rumah Hindia di zaman dahulu pada umumnya mempunyai bangunan sandingan dan terhubung dengan bangunan utama oleh selasar penghubung. Begitu juga dengan bangunan heritage Bank Indonesia ini di zaman dahulu. Bangunan ini mempunyai bentuk bagian belakang bangunan yang lurus (tidak ada tonjolan-tonjolan ruang atau bagian bangunan). Diperkirakan juga terdapat tangga luruspada bagian belakang bangunan, tangga lengkung pada teras depan, dan pada sisi kiri dan kanan bangunan terdapat jalur menuju bangunan tambahan.
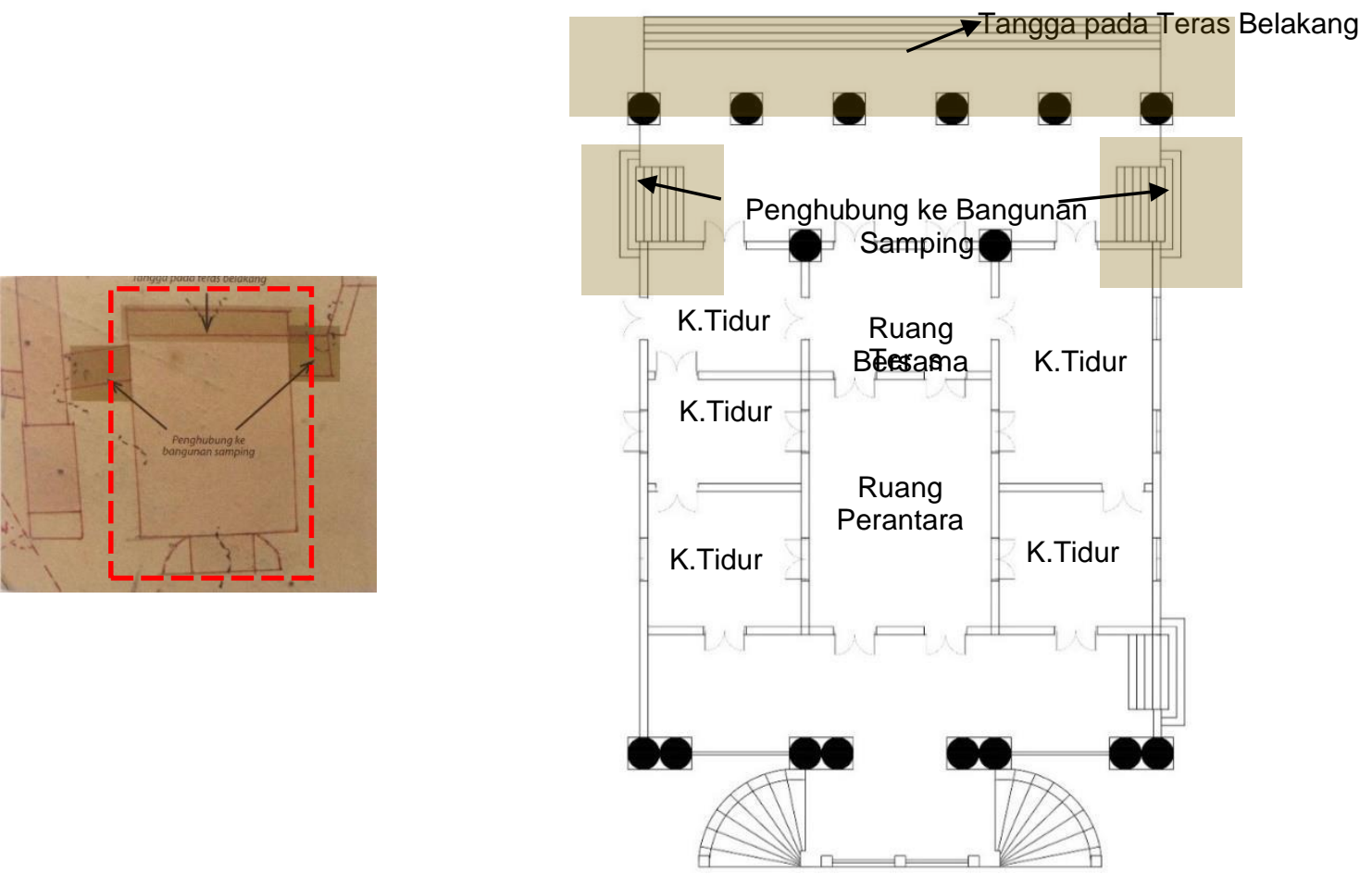

Figur 3. Perkiraan Denah Ketika Awal Dibangun (Sumber : Koleksi Pribadi)

Pada kondisi sekarang, di bagian belakang bangunan dibuat lebih tertutup menjadi ruang dalam bangunan. Teras belakang yang awalnya terbuka dengan tangga lurus diubah menjadi tertutup dengan bentuk teras menyerupai teras depan berupa tangga lengkung. Perubahan teras belakang menjadi ruang tertutup dibuat dengan menambahkan pintu-pintu panel kaca dengan kusen dan bingkai pintu yang terbuat dari besi. 


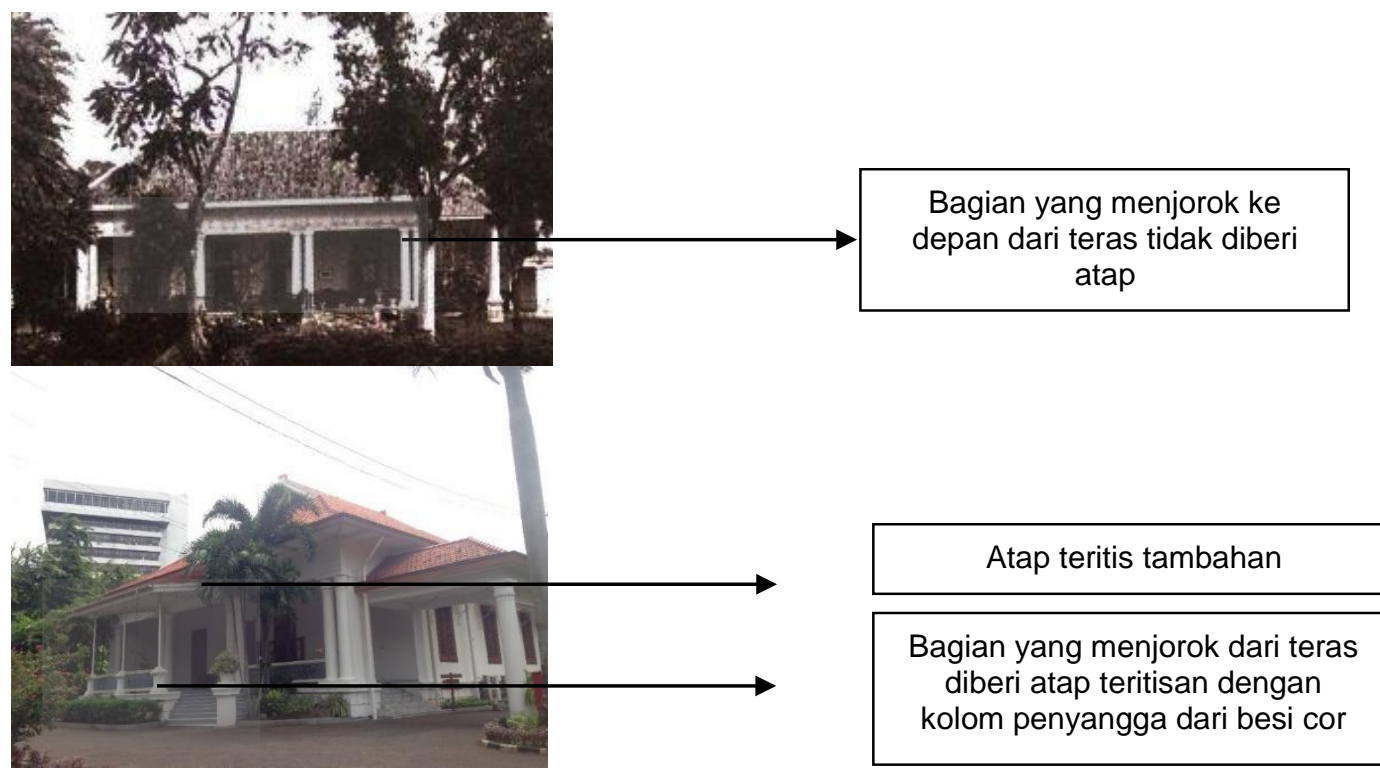

Figur 4. Perbandingan Perubahan Teras Bagian Depan Bangunan

(Sumber: Pusat Dokumentasi Arsitektur dan Dokumentasi Pribadi)

Perubahan lainnya yang sangat mencolok yaitu pada bagian depan bangunan terdapat atap teritisan tambahan yang berfungsi untuk melindungi bagian teras depan yang menjorok ke depan.

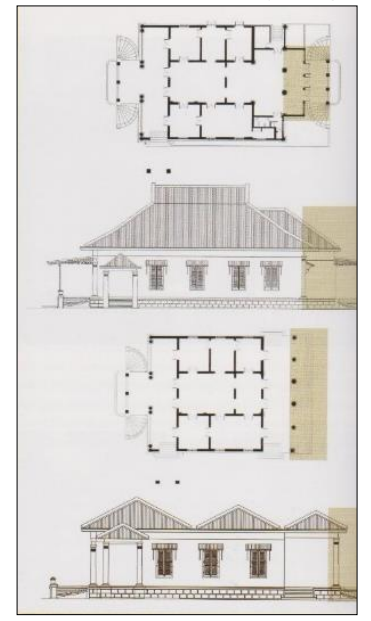

Denah Kondisi Sekarang

Tampak Samping Kondisi Sekarang

Denah Kondisi Awal Dibangun

Figur 5 Denah dan Tampak Perubahan pada Penambahasan Teras dan Teritis Bangunan

(Sumber: Pusat Dokumentasi Arsitektur)

\section{(2) Atap bangunan}

Tidak diketahui persis kapan bentuk atap rumah ini berubah, namun menurut peta udara tahun 1945 atap bangunan sudah mengalami perubahan seperti sekarang. Namun, menurut hasil wawancara dengan arsitek yang melakukan konservasi, Bapak Han Awal, beliau memperkirakan perubahan bentuk atap tersebut terjadi saat periode Sultan Hamengkubuwono tinggal di bangunan tersebut, dikarenakan terdapatkesulitan dalam melakukan maintenance dan pembersihan talang sehingga rawan terjadi kebocoran. Selain itu, bentuk atap tersebut dirasakan kurang berkesan "Jawa". 

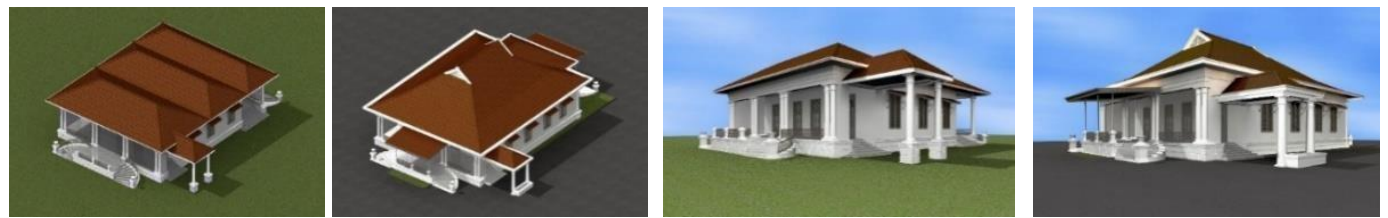

Figur 6. Penambahasan Teras dan Teritis serta Perubahan Atap Bangunan

(Sumber: Pusat Dokumentasi Arsitektur)

\section{Ruang (1) Tata ruang}

Penataan ruang-ruang dalam tidak ada yang berubah dari kondisi awal dibangun hingga sekarang. Bangunan ini tetap memiliki layout ruang dalam yang sama dari sejak awal dibangun hingga sekarang. Hanya terdapat perubahan pada bagian teras belakang yang dibuat lebih tertutup dibanding kondisi awal dibangun, hal ini telah dijelaskan di atas sebelumnya.

\section{(2) Elemen pelingkup ruang}

Elemen pelingkup ruang dapat dibagi menjadi elemen horizontal serta elemen vertikal. Elemen horizontal yaitu berupa penutup lantai bangunan. Elemen vertical berupa jendela, pintu, ornament pintu, dll.

\section{Elemen horizontal}

\section{(1) Lantai}

Keadaan penutup lantai di bangunan utama sebagian masih menggunakan material yang sama, namun sebagian telah digantikan dengan penutup lantai baru dengan motif yang mirip dengan penutup lantai awal karena telah mengalami kerusakan yang cukup parah.

\section{(2) Plafond}

Kondisi plafond seluruhnya pada saat survey tahun 2007 sudah diganti baru dan tidak layak untuk dipertahankan karena sudah mengalami penurunan kualitas akibat kerusakan atap yang cukup parah, sehingga diputuskan untuk mengganti plafond dengan material baru, sekaligus menambah titik-titik lampu utnuk keperluan pencahayaan.
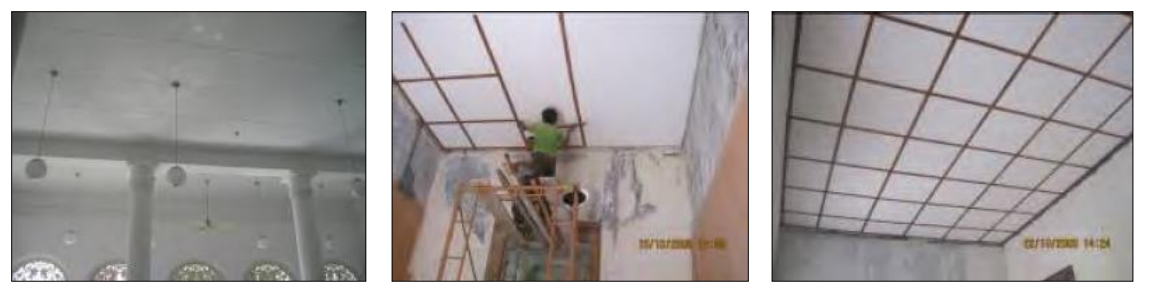

Figur7. Kondisi Eksisting - Pengerjaan - Kondisi Setelah Konservasi Plafond (Sumber: Dokumentasi PT Han Awal \& Partners dan Pusat Dokumentasi Arsitektur)

\section{(1) Struktur \\ (1) Elemen Vertikal Dinding}


Dinding dikonservasi dengan melakukan perbaikan pada beberapa bagian dinding. Seluruh permukaan dinding dan plesternya dikupas. Pada saat pengelupasan plesteran dinding ditemukan hal-hal tak terduga seperti adanya bukaan asli, namun ditutup oleh bata serta beberapa jalur-jalur pipa utilitas. Namun, diputuskan bukaan tidak dikembalikan karena adanya kebutuhan ruang yang lebih luas.
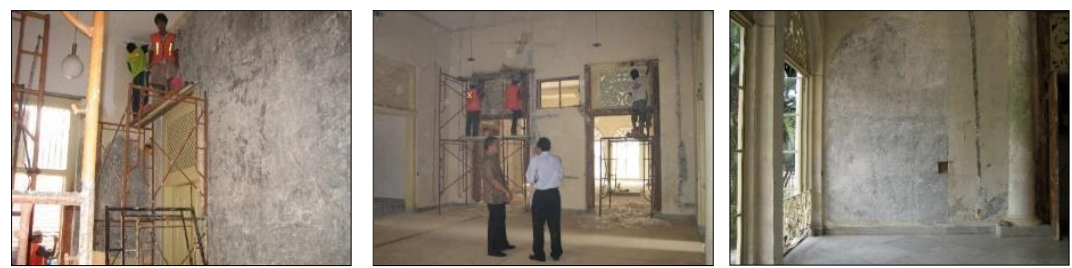

Figur8. Keadaan Konservasi Dinding

(Sumber: Dokumentasi PT Han Awal \& Partners dan Pusat Dokumentasi Arsitektur)

\section{Pintu}

Terdapat 2 jenis pintu pada bangunan ini, yaitu pintu yang berbentuk persegi panjang pada bagian atas lubang anginnya dan pintu yang memiliki bentuk lengkung pada bagian atasnya.

Penutupan pada teras belakang menjadi ruang belakang (seperti yang telah disebutkan sebelumnya) yaitu dengan menambahkan pintu-pintu panel kaca dengan kusen dan bingkai pintu yang terbuat dari besi dan memiliki bentuk lengkung pada bagian atasnya. Pintu-pintu lainnya memilki bentuk persegi panjang dengan lubang angin berbentuk bujur sangkar di atasnya.

Kusen-kusen pintu seluruhnya merupakan kusen kayu dan telah dalam kondisi dilapis cat. Kusen-kusen pintu tersebut sudah banyak yang mengalami kerusakan, kualitasnya kurang baik, serta lapuk akibat rayap.
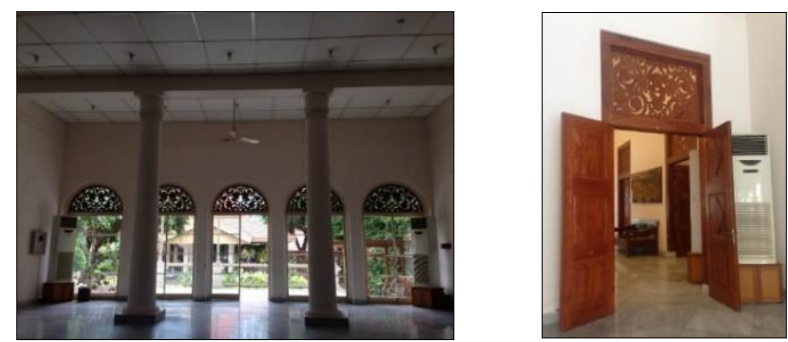

Figur9. Pintu-Pintu Berbentuk Lengkung Di Bagian Atas - Pintu Persegi Panjang (Sumber: Dokumentasi Pribadi)

Kusen kayu yang rusak tersebut sebagian diperbaiki dengan cara memotong bagian yang rusak dan menyambung dengan kayu yang seumur dan sejenis dengan kayu aslinya dengan tujuan agar kayu memiliki muai dan susut yang setara.

\section{Jendela}

Sama seperti pintu, jendela-jendela dan kusen jendela juga terbuat dari kayu dan telah banyak mengalami kerusakan akibat lapuk dimakan rayap, sehingga pada saat konservasi dilakukan perbaikan dengan cara yang sama dengan kusen pintu, dan kemudian jendela juga diplitur kembali. 


\section{Ornamen}

Pada bagian atas pintu terdapat bovenlicht dari kayu berukir motif flora dan nanas. Jika mengacu kepada foto lama, maka bentuk lubang angin tersebut seharusnya berupa silang diagonal. Menurut hasil interview dengan Bapak Han Awal, Beliau memperkirakan pada masa Hamengkubuwono IX, Beliau mengganti lubang angin diagonal menjadi ragam hias tersebut karena lebih terasa unsur Jawa, sehingga saat dikonservasi, ornamen tersebut tetap dipertahankan untuk menghormati Beliau. Namun, masih terdapat 1 pintu yang dibiarkan memilki lubang angin bermotif diagonal sebagai tanda awalnya bangunan ini memilki lubang angin bermotif silang diagonal.
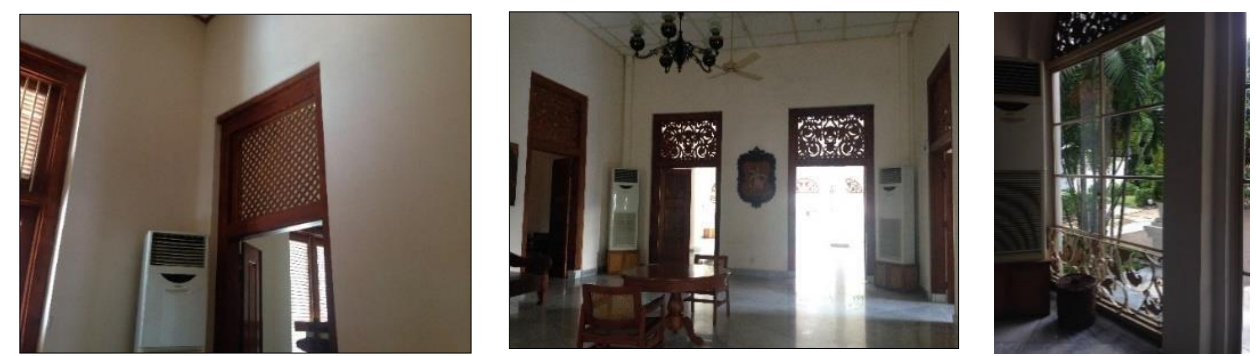

Figur10. Lubang Angin Bermotif Silang Diagonal - Lubang angin Flora - Ornamen Pagar Besi (Sumber: Dokumentasi Han Awal dan Dokumentasi Pribadi)

\section{(2) Struktur Kolom}

Kolom-kolom pada bangunan dilakukan uji coba kekuatan untuk mengetahui kualitas dan kondisi kekuatan kolom. Menurut hasil uji tersebut didapatkan bahwa kondisi kekuatan kolom masih cukup baik, hanya terdapat beberapa kerusakan plesteran kolom yang mengelupas dan retak pada teras depan bangunan maupun belakang.

Perbaikan retak menggunakan metode pengisian celah (grouting). Perbaikan plesteran dilakukan dengan bahan campuran bata merah tumbuk serta diperkuat dengan jalinan kawat ayam.
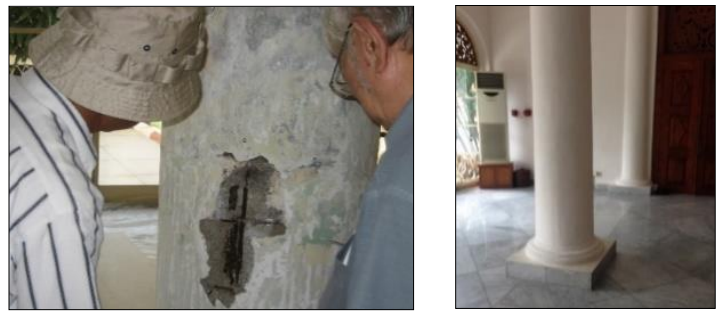

Figur11. Kondisi Eksisting Kolom Sebelum dan Sesudah Dikonservasi

(Sumber: Dokumentasi Han Awal dan Dokumentasi Pribadi)

\section{Atap}

Kondisi atap gedung sudah mengalami perubahan baik bentuk maupun material struktur didalamnya. Material eksisting struktur atap bangunan yaitu menggunakan material kayu kamper berkualitas buruk, namun setelah melalui diskusi yang panjang akhirnya pihak tim perancang, Han Awal \& Partners, memutuskan untuk menggantinya menggunakan struktur baja ringan dengan alasan memperingan beban pada dinding asli bangunan sehingga memperpanjang umur bangunan. Selain itu, juga untuk menghindari terjadinya permasalahan utama kayu yaitu rayap dan lapuk. Penutup atap juga diganti karena telah terjadi banyak kebocoran. 

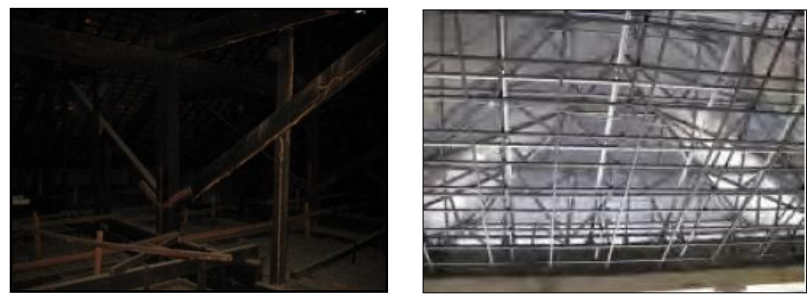

Figur12. Keadaan Eksisting Atap dengan Struktur dan Struktur Baja Ringan

(Sumber: Laporan Tim Perancang)

\section{Perubahan Penggunaan}

Terdapat perubahan penggunaan bangunan yang awalnya rumah tinggal, sekarang menjadi function hall yang bisa dipakai oleh pegawai Bank Indonesia maupun disewakan untuk umum sebagai acara pernikahan, akad nikah, gathering, dll.

\section{Fungsi awal}

Tidak diketahui secara pasti kapan tahun pembuatan bangunan ini, namun diperkirakan fungsi sejak awal bangunan ini merupakan sebuah rumah tinggal, namun seiring perkembangannya, bangunan ini telah berganti kepemilikan beberapa kali, dari milik Kan Hok Hoei seorang tokoh publik terkemuka, negarawan, bangsawan, dan tuan tanah dari Peranakan Tionghoa; pejabat De Javasche Bank - Paul Spies; Gubernur Bank Indonesia - Loekman Hakim; hingga mantan wakil presiden RI - Sultan Hamengkubuwono IX.
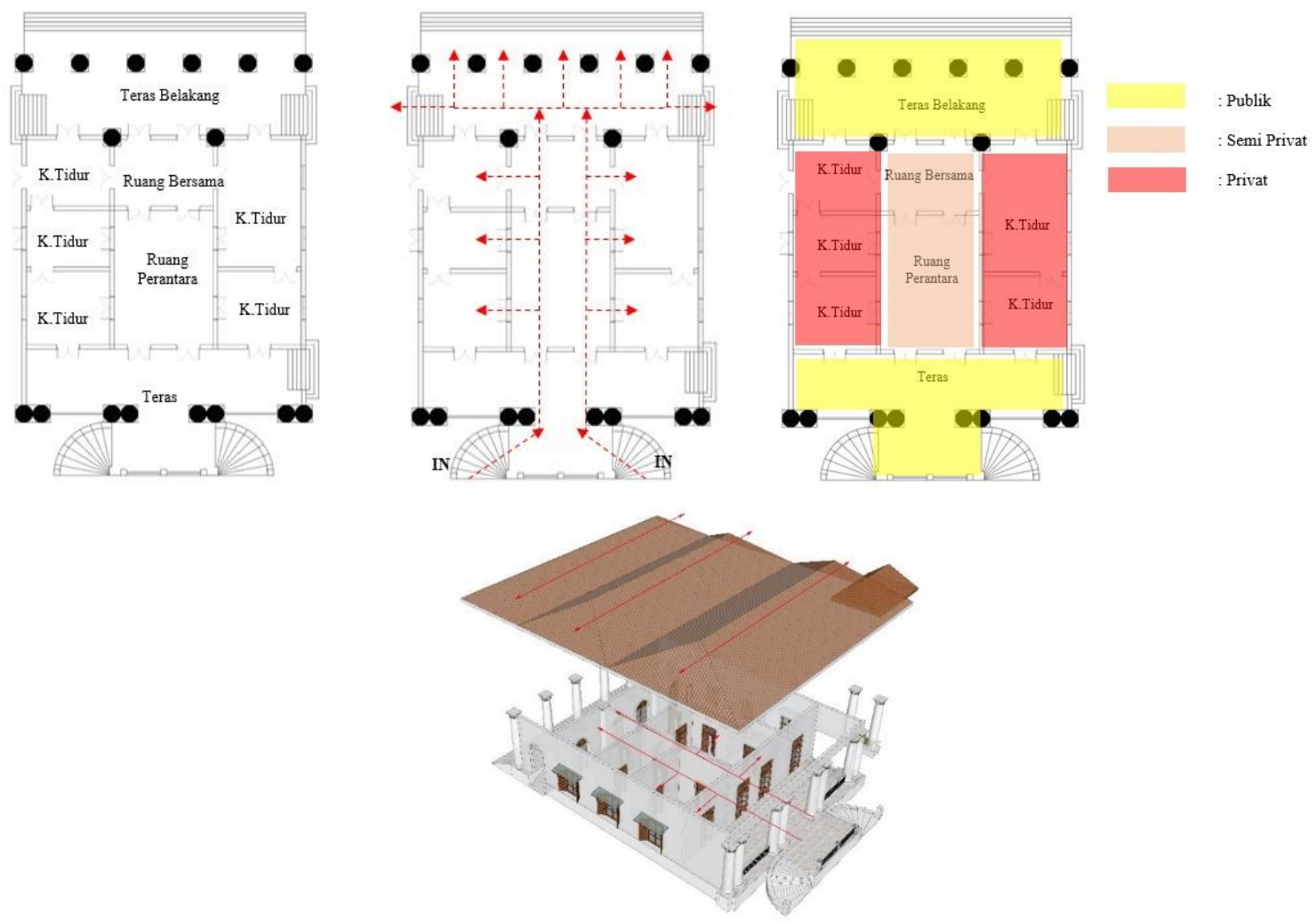
Figur13. Zoning Denah Bangunan Awal Berdasarkan Fungsi Ruang

(Sumber: Koleksi Pribadi)

Melalui skema gambar aktivitas, sirkulasi, dan ruang di atas dapat ditarik kesimpulan bahwa bangunan memiliki axis yang memanjang mengikut bentuk bangunan, namun arah atap tidak sesuai dengan sumbu kegiatan dan sirkulasi bangunan tersebut. Atap memiliki arah berlawanan dengan aktivitas dan sirkulasi yang terjadi pada bangunan. Hal ini membuat atap dan badan bangunan memiliki arah yang berlawanan.

Fungsi sekarang
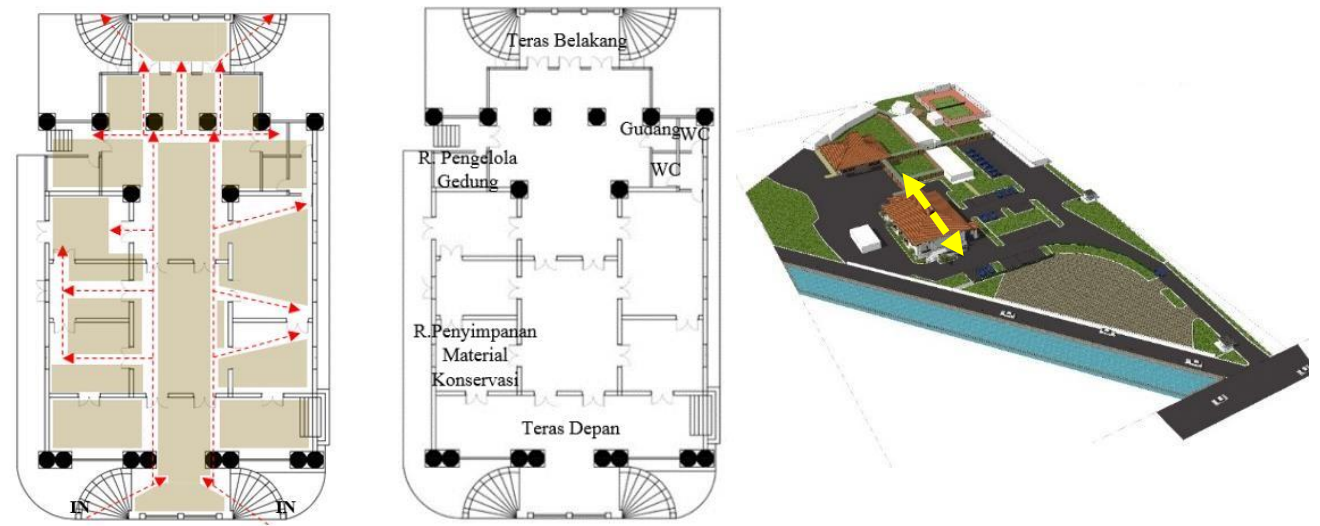

Figur14.Denah - Sirkulasi dan R. Terpakai - Axis Denah Skematik Bangunan Sekarang (Sumber: Koleksi Pribadi)

Melalui bentuk bangunan secara 3D di atas, dapat dilihat bahwa bangunan memiliki axis memanjang (linear) mengikuti bangunan. Axis linear tersebut juga dapat dilihat dari adanya kesinambungan garis sirkulasi antara teras depan dan teras belakang, selain itu keberadaan pintupintu yang simetris memungkinkan terjadinya sirkulasi linear.

Melalui aktivitas sirkulasi dan ruang yang terpakai dapat dilihat bahwa axis bangunan memanjang mengikuti bentuk bangunan. Organisasi spasial bangunan pada bangunan ini berupa linear secara hirarki ruang. Organisasi spasial yang linear dikarenakan sirkulasi ketika bangunan digunakan, memanjang melalui pintu di teras depan hingga ke bagian teras belakang bangunan.

Penggunaan bangunan heritage milik Bank Indonesia ini dibagi menjadi 2 waktu yaitu pada saat hari biasa/weekday (Senin-Jumat) dan akhir minggu/weekend(Sabtu-Minggu).

Weekday

Pada hari biasa, Senin - Jumat, gedung heritage ini tidak boleh diperbolehkan untuk disewakan oleh pihak luar, hanya diperkenankan digunakan oleh pihak internal BankIndonesia untuk acara seperti seminar, rapat, dll. 


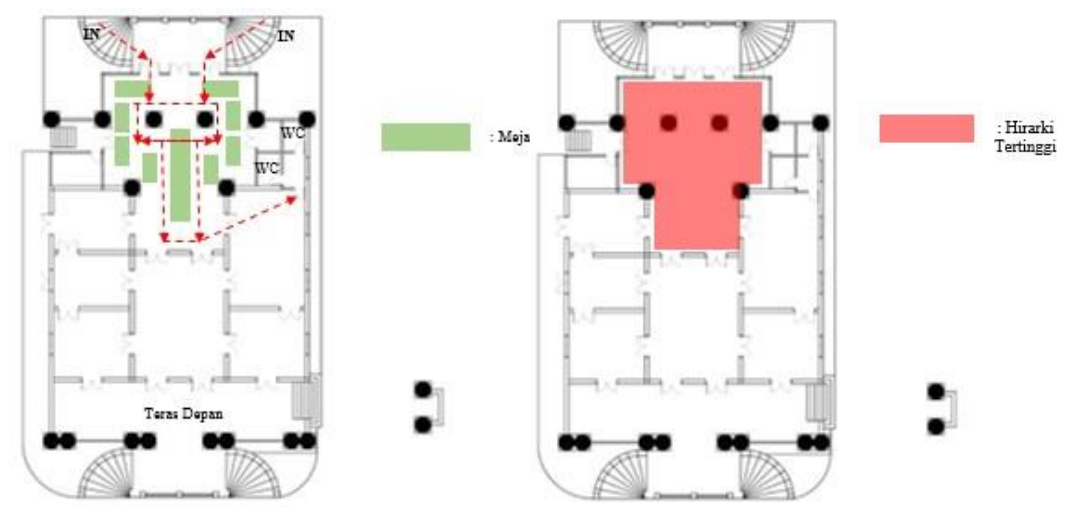

Figur15. Hirarki Ruang Skematik Denah Ketika Menjadi VenueRapat oleh Pihak BI (Sumber: Koleksi Pribadi)

Melalui gambar skematik sirkulasi dan penggunaan ruang diatas ketika digunakan menjadi venue rapat oleh pihak Bank Indonesia, dapat dilihat ruang bagian belakang tersebut merupakan ruang yang dipakai sedangkan ruang lainnya tidak digunakan. Hal ini terjadi karena dimensi ruang cukup besar dan letaknya dekat dengan area kegiatan learning center BI. Ruang belakang ini juga lebih terang dan terbuka dibanding ruang lainnya, sehingga menurut fungsi dan aktivitasnya, ruangan tersebut dianggap memiliki hirarki yang tertinggi dibanding ruang lainnya.

(2) Weekend

Gedung ini dikelola oleh PT. Spektra Kreasindo dan disewakan hanya pada hari weekend (Sabtu - Minggu) sebagai tempat pernikahan, akad nikah, gathering, dll.

\section{Akad Nikah}
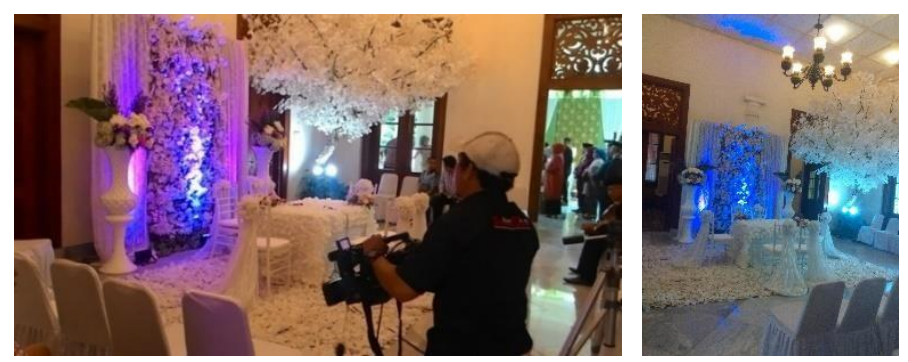

Figur 16. LayoutVenue Akad Nikah

(Sumber:: 'Akad Nikah' 2015) 


\section{Pernikahan}

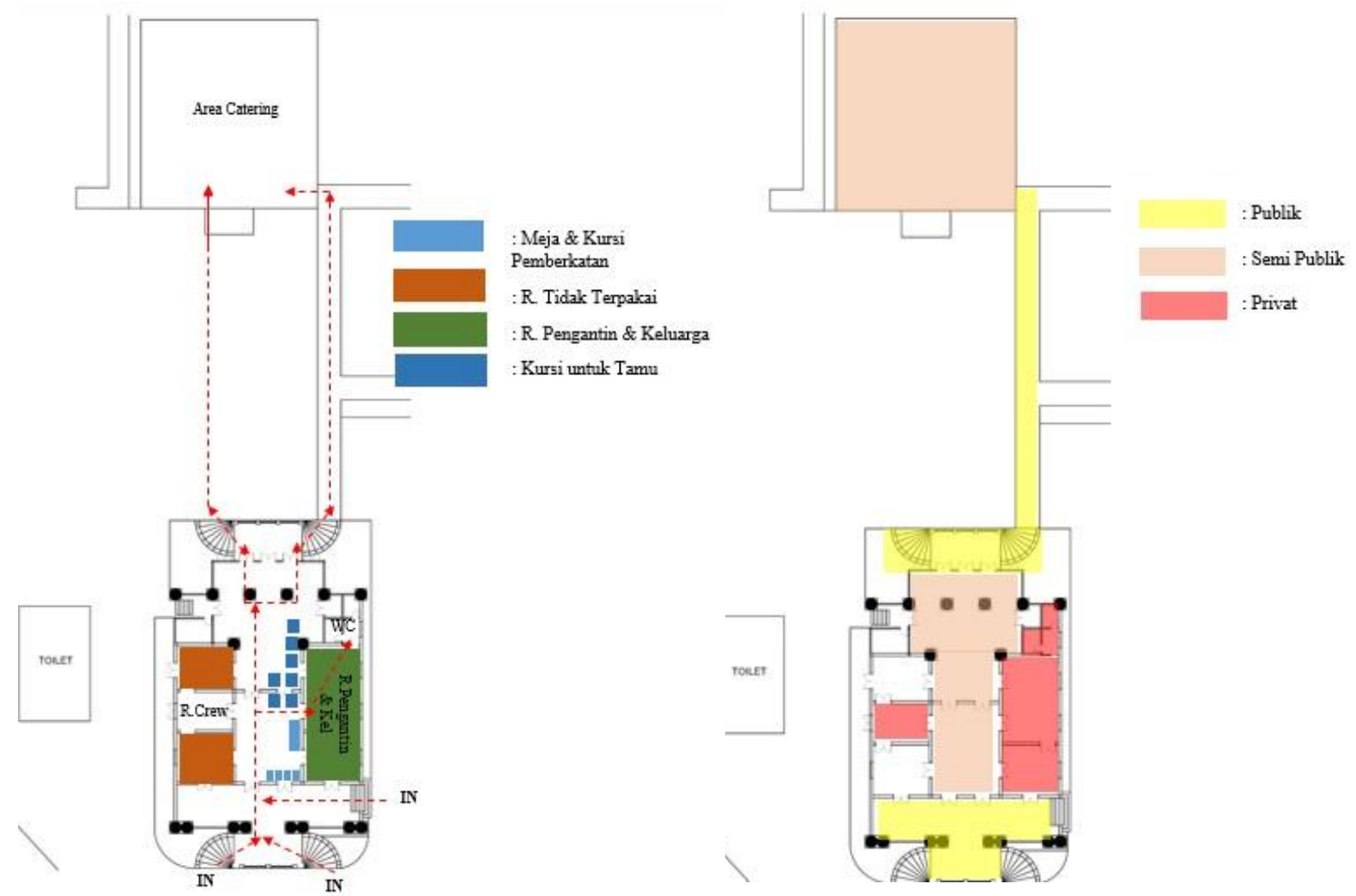

Figur 17. Sirkulasi dan Ruang Terpakai - Zoning Skematik Denah Ketika Menjadi VenueAkad Nikah (Sumber: Koleksi Pribadi)
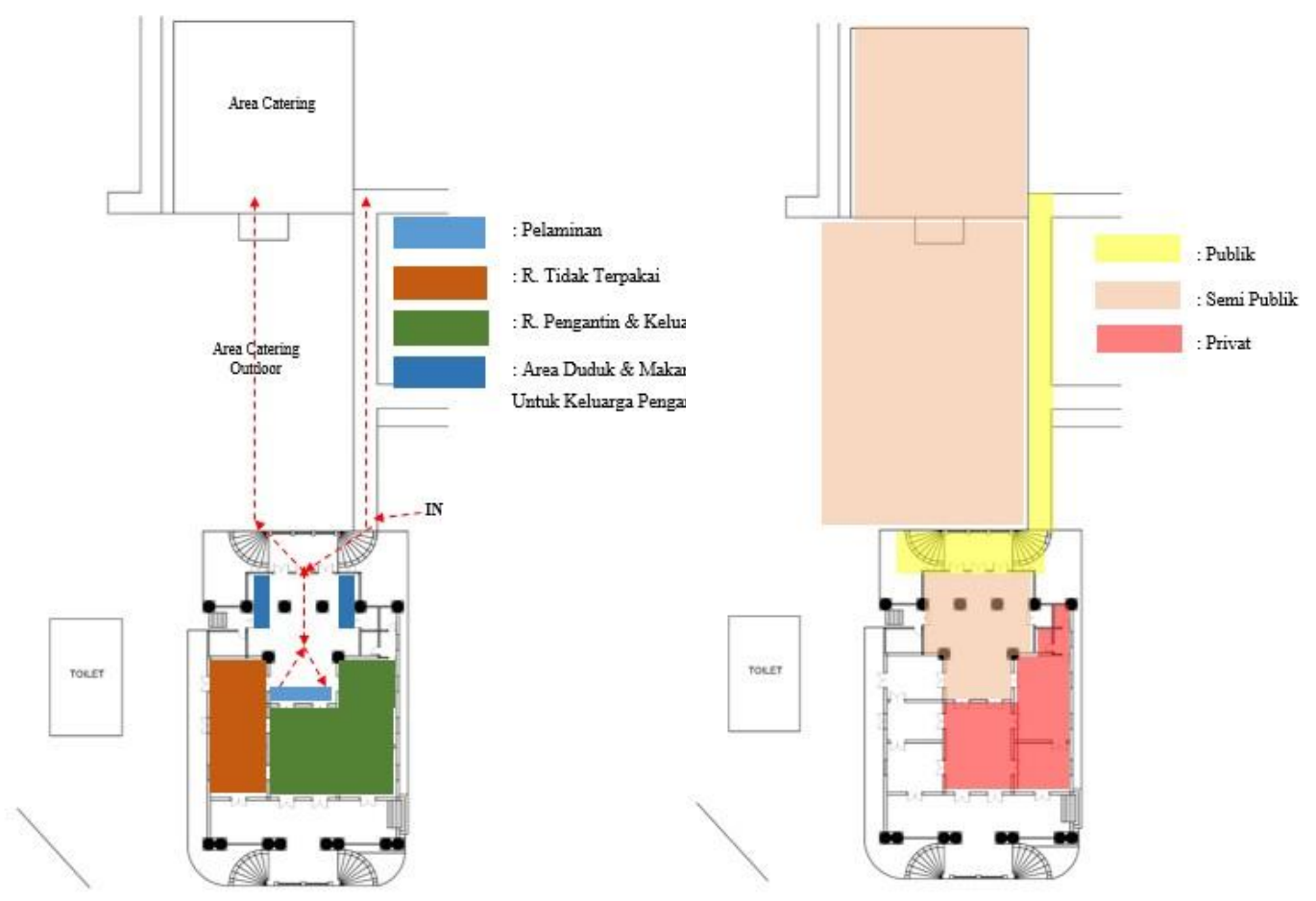
Figur 18. Sirkulasi dan Ruang Terpakai - Zoning Skematik Denah Ketika Menjadi VenuePernikahan Layout 1 (Sumber: Koleksi Pribadi)
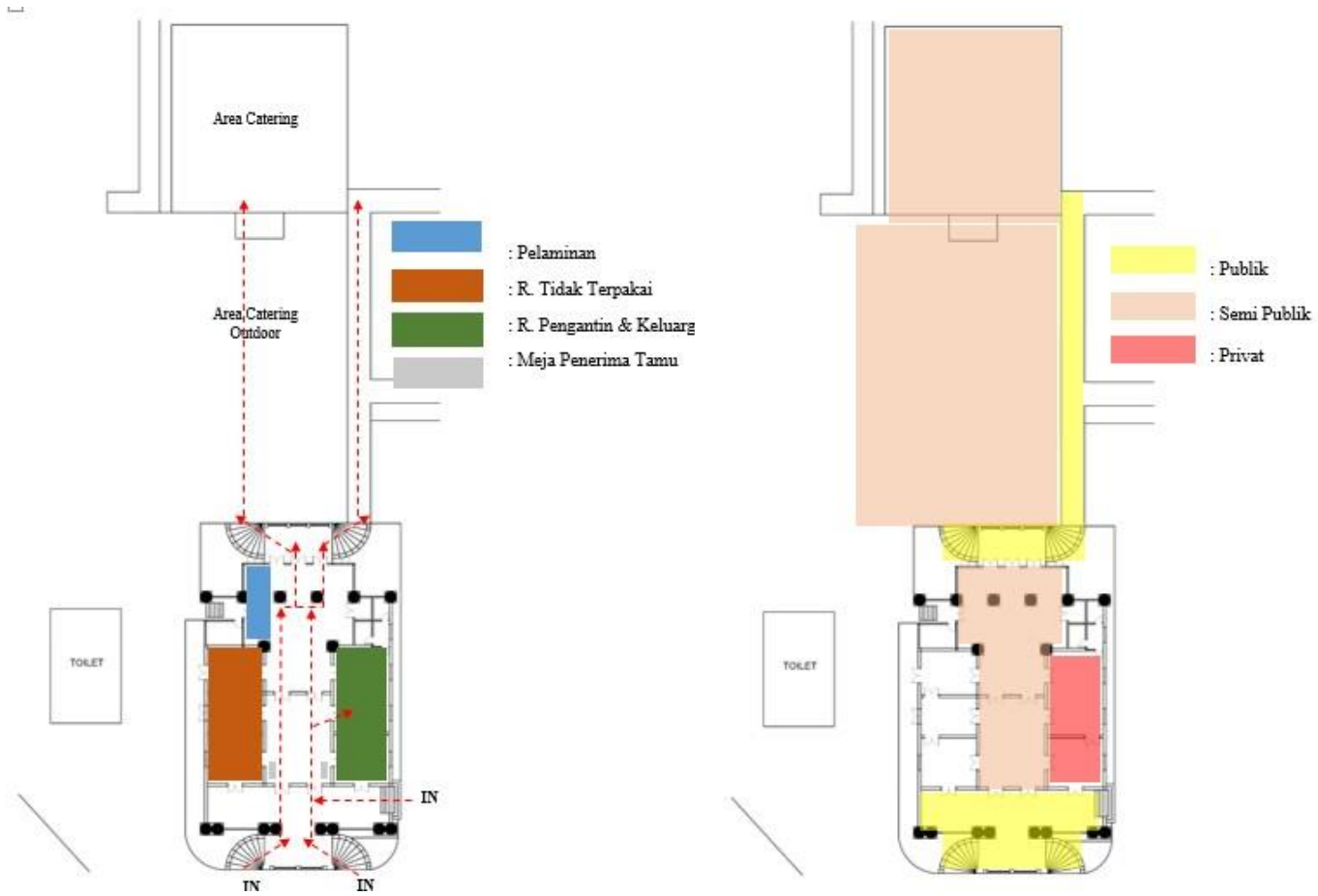

Figur 19. Sirkulasi dan Ruang Terpakai - Zoning Skematik Denah Ketika Menjadi VenuePernikahan Layout 1 (Sumber: Koleksi Pribadi)
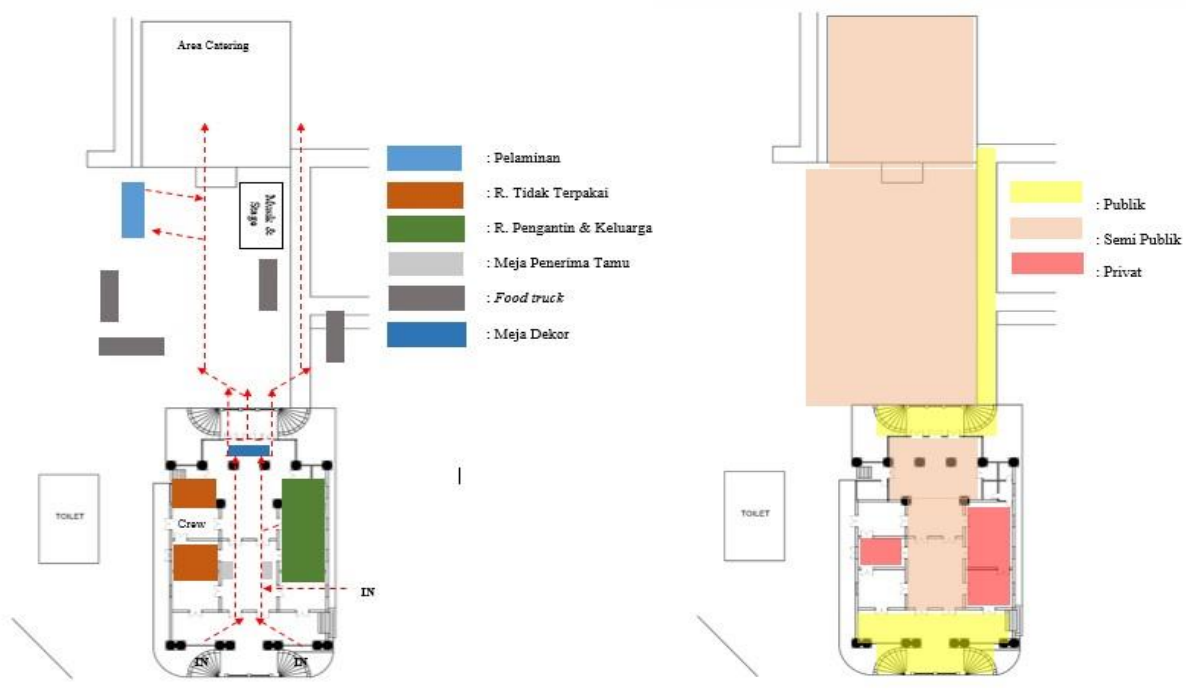

Figur 20. Sirkulasi dan Ruang Terpakai - Zoning Skematik Denah Ketika Menjadi VenuePernikahan Layout 2 (Sumber: Koleksi Pribadi) 

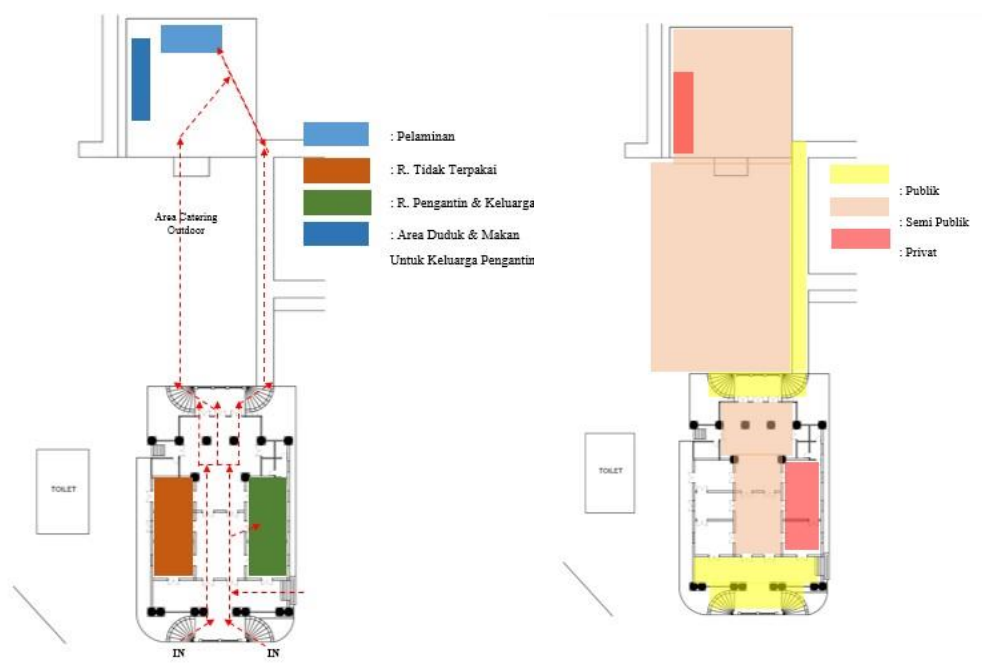

Gambar 21. Sirkulasi dan Ruang Terpakai - Zoning Skematik Denah Ketika Menjadi VenuePernikahan Layout 3 (Sumber: Koleksi Pribadi)

Dari skema gambar-gambar sirkulasi dan zoning denah ketika digunakan menjadi venuevenue yang berbeda menurut aktivitasnya maka dapat dilihat bahwa banyak sirkulasi, ruang-ruang, dan aktivitas yang tidak sesuai dengan layout dan fungsi bangunan yaitu yang awalnya digunakan sebagai rumah tinggal.

Fungsi utama bangunan yang dulunya digunakan sebagai rumah tinggal dirasakan tidak cocok ketika mengalami perubahan penggunaan / fungsi menjadi venue akad nikah, pernikahan, dll. Oleh karena itu, perlu adanya adaptasi atau perubahan yang dilakukan apabila bangunan ingin digunakan menjadi venue pernikahan, akad nikah, dll tersebut.

Perubahan tersebut seharusnya sudah direncakan sebelum bangunan dikonservasi dan direnovasi. Keputusan penggunaan bangunan menjadi venue yang bisa disewakan menjadi area wedding, akad nikah, dll tersebut justru dilakukan ketika bangunan telah selesai dikonservasi dan konservasi tersebut dilakukan tanpa melakukan perubahan-perubahan yang mendukung fungsi baru bangunan tersebut, sehingga bangunan pun tidak dapat berfungsi maksimal ketika digunakan menjadi fungsi baru tersebut (venuewedding, akad nikah, dll).

\section{KESIMPULAN}

\subsection{KESIMPULAN}

Penulis mengacu pada Perda, jurnal, skripsi yang berhubungan dengan konservasi dalam tulisan ini. Konservasi adalah suatu tindakan / usaha untuk merawat, melestarikan, dan melindungi suatu bangunan yang memiliki nilai bersejarah atau makna kultural di dalamnya. Konservasi merupakan sistem yang berkelanjutan yang tidak hanya memperhatikan aspek arsitektural, namun juga ekonomi dan sosial. Konservasi yang dilakukan pada bangunan ini hampir semua aspek telah sesuai dengan prinsip-prinsip dasar dalam tindakan konservasi bangunan heritage, hanya aspek penggunaan bangunan yang belum memenuhi. Hal ini karena, sebelum konservasi dilakukan, penggunaan bangunan tidak dipertimbangkan akan digunakan sebagai apa bangunan ini di masa mendatangnya. 
Dapat disimpulkan bahwa bangunan heritage Bank Indonesia di Jl. Prapatan No. 42 ini tidak mengalami berbagai macam perubahan. Ruang-ruang, ornamen, dan material tidak mengalami perubahan yang signifikan. Apabila terdapat komponan-komponen yang mengalami kerusakan, dilestarikan sesuai dengan keadaan ketika Sultan Hamengkubuwono IX tinggal. Perubahan signifikan yang terjadi yaitu pada material struktur atap, dari kayu menjadi baja ringan.

Perubahan signifikan lainnya, yaitu terdapat pada fungsi bangunan. Bangunan digunakan sebagai rumah tinggal ketika awal dibangun, namun seiring waktu dan kondisi yang terjadi, bangunan kemudian berubah fungsi menjadi venue yang bisa disewakan menjadi tempat pernikahan, akad nikah, gathering, dll pada hari weekend dan ketika hari weekday hanya dapat digunakan oleh pihak internal Bank Indonesia.

Secara umum, dapat disimpulkan bahwa pemakaian ruangan pada bangunan heritage Bank Indonesia menjadi tidak efektif setelah dikonservasi. Fungsi bangunan mengalami perubahan yang cukup signifikan namun tidak diikuti dengan penyesuaian fungsi yang baru, sehingga menyebabkan bangunan menjadi terasingkan dan tidak sesuai dengan konteks lingkungannya yang berada di dalam kompleks learning center Bank Indonesia.

\subsection{SARAN}

Bangunan heritage Bank Indonesia merupakan salah satu bangunan yang memiliki nilai sejarah mengenai perkembangan arsitektur di Indonesia khususnya arsitektur rumah tinggal dengan gaya indis. Oleh karena itu, dilihat dari nilai sejarah dan ilmu, bangunan ini sangat penting untuk dilestarikan dan dijaga. Diperlukan tindakan konservasi bangunan yang tidak hanya mempertahankan nilai bangunan secara fisik saja, melainkan juga nilai yang melekat pada bangunan.

Tindakan pemilik bangunan - Bank Indonesia untuk mengkonservasi bangunan ini sudah sangat baik, menandakan sudah adanya kesadaran akan pentingnya bangunanbangunan lama yang dapat dijadikan bukti peninggalan dan pembelajaran di zaman sekarang, tetapi masih ada beberapa hal yang kurang sesuai.

Seiring dengan perubahan waktu, fungsi bangunan juga mengalami perubahan dan berbeda dengan fungsi asli. Perubahan fungsi tersebut disarankan perlu dicermati dan dianalisa secara mendalam. Sebelum dikonservasi, fungsi bangunan harus dipikirkan secara matang apakah mengikuti fungsi awal atau hendak berubah fungsi, sehingga konservasi seharusnya menyesuaikan dengan perubahan tersebut.

Selain itu, konservasi bangunan juga harus mengikuti pedoman-pedoman konservasi yang telah ditetapkan pemerintah serta pihak yang ahli dalam bidang tersebut, sehingga konservasi dapat dilakukan tanpa menghilangkan nilai-nilai sejarah pada bangunan tersebut.

\section{DAFTAR PUSTAKA}

Atmadi, P. 1988. Some Architectural Design Principles of Temples in Java: A Study through the Buildings Projection on the Reliefs of Borobudur Temple, Yogyakarta (Java, Indonesia): Gajah Mada University Press.

Ching, DK. 2008. Bentuk, Ruang, dan Tatanan. Jakarta: Erlangga 
Eryudhawan, Bambang, Purwestri, Nadia, dan Suryaningsih, Febriyanti. 2010. Rumah Hindia di Tepi Sungai. Jakarta: Direktorat Logistik dan Pengamanan Bank Indonesia

Jessup, Helen. 1988. Netherlands Architecture in Indonesia, 1900-1942. London: University of London.

Kunto, Haryoto (1985), Wajah Bandung Tempo Doeloe, PT. Granesia, Bandung Kunto, Haryoto (1986), Semerbak Banga Di Bandung Raya, PT. Granesia, Bandung.

Murtagh, William. 2005. Keeping Time: The History and Theory of Preservation in America. Canada: John Wiley \& Sons, Inc.

Orbasli, Ayin. 2008. Architectural Conservation: Principles and Practice. Oxford: Blackwell Science Ltd

Rypkema, D.D. (1992). Rethinking Economic Values. In: Lee, Aj (ed). Past Meets Future: Saving America's Historic Environment. The Preservation press, Washington DC.

Soekiman, Djoko. 2000. Kebudayaan Indis: dan gaya hidup masyarakat pendukungnya di Jawa (abad XVIII - Medio Abad XX). Yogyakarta: Yayasan Bentang Budaya

Sumalyo, Yulianto. 1995. Arsitektur Kolonial Belanda di Indonesia. Yogyakarta: GadjahMada University Press.

Snyder, James C. (Editor). Perencanaan Kota: 413-438. Jakarta: Erlangga.

Tiesdell, Steven., C, Tanner O., Heath, Tim (1996). Revitalizing Historic Urban Quarters. Architectural Press

Peraturan Daerah Kota Jakarta No. 9 Tahun 1999

Undang-undang Republik Indonesia No. 11 Tahun 2010

Handinoto. 1992. Perkembangan Kota dan Arsitektur Kolonial Belanda di Surabaya1870-1940 Handinoto. 1994. Indische Empire Style.20: 1

Muliadi, Andi, Umulolo, “Upaya Penanganan Kayu Secara Tradisional”, Vol.3, Hlm 16

Mundardjito, 1995, Pendekatan Integratif dan Partisipatif Dalam Pelestarian Budaya. Jakarta: FS Universitas Indonesia.

Mundardjito. 2002. Pertimbangan Ekologis Penempatan Situs Masa Hindu-Buda di Daerah Yogyakarta. Jakarta: Wedatama Widya Sastra dan Ecole Francaise D'extreme-Orient.

Pontoh, N.K. 1992. Preservasi dan Konservasi Suatu Tinjauan Teori Perancangan Kota. Jurnal PWK, IV (6): 34-39.

Sukawi. 2009. Perkembangan Kota dan Arsitektur Kolonial Belanda di Surabaya 1870-1940. Jurnal Tesa Arsitektur. 7:42-44 